\title{
Paragenese of the vegetation in ecosystems contact zones (in Lake Baikal basin)
}

\author{
Alexander Sizykh ${ }^{1^{*}}$, Victor Voronin $^{1}$, Michail Azovsky $^{2}$, Svetlana Sizykh $^{3}$ \\ ${ }^{1}$ Siberian Institute of Plant Physiology and Biochemistry, Siberian Branch of Russian Academy of Sciences, Irkutsk, Russia; \\ *Corresponding Author: alexander_sizykh@yahoo.com \\ ${ }^{2}$ Institute of Geochemistry, Siberian Branch of Russian Academy of Sciences, Irkutsk, Russia \\ ${ }^{3}$ Botanic Garden, Irkutsk State University, Irkutsk, Russia
}

Received 4 May 2011; revised 12 June 2011; accepted 2 July 2011

\begin{abstract}
Phytocenoses in the ecosystems contact zones are characterized by a rather complex structural and dynamical more than one features and by specific development characters under definite physical and geographical conditions. Unlike zonal vegetation, such phytocenoses respond to all environment changes more rapidly. The structure of such phytocenoses allows to determine the way this or that scenarios of climate change would develop at any level of more than one ecosystems. A possibility to use the notion "paragenese" for characterization of phytocenoses under contrast conditions is considered. Paragenese is the development of phytocenoses which are not related to zonal vegetation types by their composition and structure. Probably, the communities from ecosystems contact zones are to be related to a particular "type" of vegetation. Phytocenoses in the contact of light coniferous taiga and extrazonal steppes, as well as relations between zonal forest-steppe at main areas of Lake Baikal basin served as examples for justification of use of the notion "paragenese" to characterize the development of such communities.
\end{abstract}

Keywords: Paragenese; Phytocenoses; Lake Baikal Basin; Ecosystems

\section{INTRODUCTION}

Paragenese is forming the plant communities inside of the zonal vegetation but they are very distinctive by structure and dynamics from zonal plant communities. We belive papagenese is a phenomenon which can serve as a base in the studies of plants species biology, of phytocenoses ecology, and of genesis of the whole environment.
Taking into account climate dynamics, forecasting becomes an essential aim of studies of processes of probable changes in the vegetation at vast territories. Any forecast requires complete information on actual state and ancient changes in vegetation characteristic for the period of formation of its main structural and dynamical parameters. Forecasts are hypotheses of long-term vegetation transformations for actual natural conditions of a concrete territory, and even more for changing environment.

A part of such forecasts is modeling of vegetation successions given the existing dynamics of landscape-forming factors. The obtaining of fundamental information for forecasts is possible by establishment of a network of model territories showing real structural and dynamical features of definite environments as they are understood presently [1-3], as well as features of intrazonal and interzonal environment differences. The vegetation of model territories can serve as a succession system reflecting all possible states of communities at actual endoecogenesis and exoecogenesis of vegetation at a concrete territory.

Models can be a base for obtaining information that allows correction of existing successions schemes not only for zonal vegetation, but also for phytocenoses of transitional territories. Moreover, phytocenoses in ecosystems contact zones reflect all changes of the background climate dynamics more rapidly than zonal vegetation as it is understood nowadays. Due to this, other information base appears for theoretical hypotheses concerning age, place and role of basic or transitional communities in successional systems at any climate changes. Consequently, such information will be a basis for a longterm forecast of any vegetation changes.

\section{BACKGROUND}

Zonal and altitude-zonal differentiation of environmental parameters determines forms and types of changes in formation of vegetation of any hierarchy. Under dyna- 
mic climate conditions, shifts of natural (geographical) zones and of altitudinal zones occur, these processes result both in changes of ecosystem boundaries, and in polyzonal vegetation differentiation [4-7]. Determination of the consequences of such changes is an important problem in the assessment of any changes both in vegetation and in the whole environment.

Recently there appeared opinions about the increase of ecotonization processes of biota in the whole and of vegetation in particular [8]. It is traditional to consider ecotones of different character and size-from marginal and interzonal to transcontinental ones [9,10]. It is doubtful that such approaches for determination of concrete phenomena can be considered as productive ones, as the meaning of the notion "ecotone" in the references mentioned has a very conventional character. E.g., telling about taiga, we mean a forest where coniferous trees dominate. It is evident to revise the concept "ecotone", maybe this phenomenon is to be considered as an independent environment "type" with classification (hierarchy) by volume, size of a plots and geographical environment.

Recently it has been proposed to determine a new ecology branch: ecotones ecology; its subject will be ecotones systems of any level. i.e., here ecotones are also considered as ecosystems different by their volume, territory relation and genesis of natural phenomena.

Current postulations in theoretical phytocenology and ecology add up to the understanding of the necessity of creating models for holistic characteristics of any systems-communities, biogeocenoses, ecosystems. We understand it as an analysis of existing processes, in particular, as regards vegetation, which requires the study of all changes in communities for concrete conditions for any time period. This has every chance of success at the modern stage of vegetation studies.

\section{AIM AND TASKS OF INVESTIGATION}

Our aim and tasks are to reveal the diversity in composition of phytocenoses under transitional conditions in Lake Baikal basin. Changeability of communities structure in ecosystems contact zones presents in the most detailed way the processes of formation of vegetation cover in vast areas on the background of climate dynamics in any region. Essentially, such phytocenoses are indicators of past, present and future changes in the development of vegetation in the region. Communities in the contact area of light-coniferous and dark-coniferous taiga, forest-steppe and steppe under zonal or altitudinal belts conditions, in our opinion, are natural models of indications of any changes in the environment.

We used as methodology in our studies theses on paragenese of environments. There are different opinions on this matter [11-13]. We have no aim to present the pre- history of the appearing of the notion "paragenese". We are going to present examples of the characteristics of this phenomenon for different environments which are, on our opinion, essential.

\section{SOME EXAMPLES OF PARAGENESE IN THE ENVIRONMENT}

Characterizing Crimea zones as a paragenetic system, the author considers the relief as main factor of differentiation of its structure. In his opinion, the relief determines zones of paragenetic systems, such as hydromorphic plakor-steppe one, mean-mountain-pre-mountain forest and forest-steppe one, mean-mountain-low mountain forest one. These three systems differ, but at the same time they are connected by geomorphological and biocenological peculiarities of their structure. It means that intensive intra-landscape links which are due to some types of metabolism and energy exchange are observed between zones situated at different landscape levels. These links are related to paragenetic type. The author [11], concludes that mean-mountain-pre-mountain and mean-mountain-south coast polygenetic systems are united as a mean-mountain-pre-mountain system due to polysystematic biocenological links. As for mountain and plain system, they are united by paragenetic links. Main intralandscape geomorphological and biocenological links between zones are multistage systems of paragenetic type.

However, characterizing paragenese as a system of matter and energy links between different territories, the author [11], observes the classical definition of the notion "native zone". It implies existence of interzonal native systems. In our opinion, it is difficult in this case to determine, where there is paragenese, and where there is continuity, multi-systems or successions system reflecting the dynamics of one phenomenon at different periods of its formation.

There are very interesting theses on elementary morphology of highlands in Southern Siberia characterizing the peculiarities of mountain relief development in this region. The author [12] who analyzes opinions of different researchers concerning using of notion "paragenese" in relief formation makes a conclusion that in the characteristics of any processes, this notion is interpreted differently. Paragenese is considered as "genetic succession, successive development, changing or transition from one phenomenon to other one, a combination based on a common origin of its compounds, but genetic links are not very necessary" [12]. The author presents also his own opinion that it is necessary to distinguish the notions "paragenese" and "paragenesis" as they are different. He agrees with existing statement in geology and geochemistry, where "paragenese" is a object, and "paragenesis" is a phenomenon. This is spatial and tem- 
poral combination of objects of the same level but of different appearance. We have to agree with these statements as, in our opinion, a whole united phenomenon is determined by the variety of its states in space and time.

Studying processes of soils formation in Trans-Baikal [13], researchers discuss also different ways of soils development. This is due both to relief and climate peculiarities, and to human impact onto the environment of this region. According to the results of soils formation studies done by some researchers, the authors conclude that paragenesis is "regular spatial combination of biogeosystems, soils and soils combinations. Paragenetic systems are catenas, soil series, mountain chains and geochemical landscapes consisting of elementary landscapes" [13]. They agree that biogeosystems formation occurs in temporal conjugation and believe that conjugated biogeocenoses have the same or similar processes with unilateral or bilateral metabolism and energy exchange. The closer they are situated, the more synchronous are dynamic processes in them. Such dynamic processes are called paradynamism.

However, in this case trend and dynamics of soil formation processes also depend directly on the relief structure determining the specific of matter income and soils formation time.

Due to this fact, the definition of paragenesis as of a consistent integrity and of spatial combination of biogeosystems which appeared simultaneously or subsequently in close links with each other.

\section{Discussions about Conditions of Paragenese Formation}

Thus, the statements of different authors on this matter add up to the thesis that artificial subdivision of environments onto certain groups may be not unbiased and not appropriate. Any phenomenon reflects processes of territory development "now and here" under existing conditions. If we observe under certain conditions different processes, e.g., steppes in taiga or a forest among steppes (the most often at regional or topologic environment level), we have to mean probably paragenese as a real process reflecting some existing conditions during certain time interval. If climate changes and results in changes in the whole environment, conditions of formation of these environments also change. It results, e.g., in formation of steppe communities among taiga forests.

Formation of natural systems, including vegetation, occurs simultaneously under existing physical and geographical conditions. In the past time, environments under the same climatic conditions also differed, e.g., by vegetation. As environment changed (i.e., native zones boundaries as it is understood nowadays), spatial combination of biogeocenoses (communities) also changed depending on relief structure. Just the relief was a factor of spatial differentiation of some phenomena. However, development of any environmental systems occurs at a certain territory always simultaneously.

We consider vegetation paragenese from the viewpoint of probability of formation of phytocenoses diversity under existing conditions within certain territories which are called "native zones" (altitudinal belts) as they are understood nowadays. Phytocenoses in environments contact areas, i.e., in interzonal (interaltitudinal) communities within native zones serve as an example of paragenese. This is a natural process of development of conjugate communities with similar metabolism and energy exchange.

Spatial structural modifications of Baikal region vegetation occurred due to climate dynamics in Holocene, but at that time there existed as well different processes of vegetation formation due to peculiarities and diversity of environmental conditions at different levels. There were no "direct" ways dividing different vegetation "types" in Holocene (as well as in the whole Cenozoic); there are no such ways nowadays; there will be no such ways in the future as environmental conditions on any territory will always differ due to heterogeneity of relief and climate at any time period. As well there is no "reversal" way of development. Thus, during each Holocene period there occurred processes which can be characterized as paragenese. We can observe the same phenomenon in formation of modern vegetation in Lake Baikal basin. It is confirmed by the results of studies of character of interactions between taiga and extrazonal steppes, between insulated steppes of depression type and light-coniferous forests, between zonal forest-steppes (as they are understood nowadays) and steppes.

\section{RESEARCH METHODS AND AREAS}

During 21 research years (from 1988 till 2008) using methods of field geobotanic survey and making largescale geobotanic maps on the base of field deciphering of medium- and small-scale (1:100,000 and 1:25,000) air photos and spatial photos made in different periods, we revealed main structural and dynamic peculiarities of vegetation in two main sites in Lake Baikal basin. In combination with geobotanic descriptions (total ca. 900) and integral soil and geobotanic profiling (scale 1:10,000 and 1:50,000), the monitoring of phytocenoses dynamics at some territories was performed.

The monitoring was performed during different periods of plants vegetation. Two key sites were studied in this research: 1) central part of the western shore of Lake Baikal, and 2) central part of Selenga River valley (south of Zabaikalaya).

Model territories of the key site in the central part of the Western coast of Lake Baikal (Pre-Ol'khon) served as reference points for perennial studies of the peculiari- 
ties of formation and development of phytocenoses in the contact area between light-coniferous taiga and extrazonal steppe communities. The second model territory is situated in the contact area between forest-steppes and steppes communities, it was used for comparative analysis of the peculiarities of vegetation development under the condition of division into zones, as it is understood nowadays.

\section{RESULTS}

As a result of the research performed, new data characterizing the peculiarities of phytocenoses development formed under different physical and geographical conditions were obtained. Extra-zonal effects in the state of vegetation cover are characteristic for the vegetation of model territories on the key site in taiga zone, in the central part of Lake Baikal Western coast (Pre-Ol'khon). On large-scale geobotanic maps of two model territoriesTalovka River basin (southern part of Pre-Ol'khon) and Maloye Morye coast (Central Pre-Ol'khon)_detailed structural and dynamic parameters of phytocenoses in the contact area between taiga and extra-zonal steppes are presented.

Main characteristics of phytocenoses in the contact area between taiga and extra-zonal steppes are:

1) The vegetation of a model territory Talovka River basin (southern part of Pre-Ol'khon) is characterized by different contact of forests with green mosses containing also Larix sibirica, Duschekia fruticosa, Rhododendron dauricum with external cover containing Rhytidium rugosum, Drepanocladus unicinatus, Dicranum polisetum, Ptilium crista-castrensis, Polytrichum juniperinum, Mnium cuspidatum, Abietinella abietina and forests containing pines Pinus sylvestris, sparse grasses, as well as Rhododendron dauricum with Iris ruthenica and Pyrola rotundifolia, Vaccinium vitis-idaea with areas containing extra-zonal steppe communities where Poa botryoides, Agro-pyron cristatum, Veronica incana, Galium verum, Po-tentilla tanacetifolia, etc. dominate. Grass communities here are synusial and are due mainly to such violation as fires and forest cutting. Species composition of such communities includes both steppe and meadowforest (taiga), meadow plants species. Everywhere among steppe communities there are beds and regrowth of Pinus sylvestris, sometimes of Larix sibirica.

2) As for the vegetation of another model territoryMaloye Morye coast (central part of Pre-Ol'khon), here in all the forest larch dominates with underbrush consisting of Rhododendron dauricum, mosses are abundant in the soil cover, these are Rhytidium rugosum, Drepanocladus unicinatus, Dicranium polisetum, Climacium dendroides, Hyloconium splendens, Pleurozium schreberii, Rhytidiadelphus triquetrus, etc. We have to notice that Pinus sibirica aged from 2 to 28 occurs among larch forests of this model territory, and mosses are edificators of soil cover of polydominant light- and dark-coniferous forests (taiga) which are typical for the whole Pre-Baikal.

Steppe communities occupy rather large territories where the following species dominate: Poa botryoides, Festuca lenensis, Chamaerhodos altaica, Potentilla tanacetifolia, Astragalus versicolor, Scabiosa comosa, Artemisia frigida, etc. Among these steppe communities, larch Larix sibirica aged from 2 to 40 is developed, there are some trees aged up to 150 . Perennial monitoring (during 21 years) of the dynamics of vegetation formation on these model territories allowed to reveal and to state particular type of phytocenoses-taiga-steppe ones. These communities are a dynamic stage in the development of forest in Western Pre-Baikal taiga zone. The development of vegetation in this part of Lake Baikal basin is to be characterized as an example of vegetation paragenese in taiga zone as it is understood nowadays.

Concerning the vegetation on the second key sitecontact area of steppes and zonal forest-steppes, the development of transitional communities is typical here. They consist of Stipa krylovii, Artemisia frigida, Potentilla acaulis, Festuca lenensis, Poa botryoides, etc. In the forest communities with soil cover consisting of foreststeppe plants species, undergrowth and young growth are higher than forest canopy. Mosses are not found.

\section{DISCUSSIONS}

We have to notice here that activation of forest expansion onto steppe territory is mainly due to decrease of human impact, e.g., of use for grazing. However, climate changes also impact the dynamics of vegetation in the forest-steppe zone of this part of Western Trans-Baikal. Probably, the spatial changeability of the boundary of zonal forest-steppes as of autonomous vegetation type (native zone) is due just to climate change. Is it possible to tell here about vegetation paragenese? We suppose that in this case there is interzonal paragenese, it corresponds to some degree to statements of some researchers. Their opinions are presented in the introduction of this very article. However, geological or geochemical paragenese or soils paragenesis are phenomena of different nature, and vegetation is a more dynamic compound of ecosystems. In our opinion, the vegetation paragenese in the environments contact area, in particular, one of Lake Baikal basin, is to be considered as manifestation of environmental conditions (relief structure, temperature and humidity dynamics) on a concrete territory. It can be presented at local (topological), regional (including basins of large water bodies and rivers) and continental levels of environment.

If we consider vegetation paragenese as a polyzonality phenomenon, we have to modify the sense of the notion "native zone". Maybe, vegetation paragenese in the en- 
vironments contact area is a manifestation of ecotones of different size as they are understood nowadays? However, paragenese phenomenon is characteristic for intrazonal environments rather than for interzonal ones.

\section{CONCLUSIONS}

We believe that paragenese both includes and reflects the specifics of condition of vegetation formation conditions on the background of climate dynamics and changeability. The vegetation in the environments contact areas is just the most evident paragenese manifestation. Phytocenoses diversity of first of all typological and classification importance is due just to paragenese. This phenomenon can serve as a base in the studies of plants species biology, of phytocenoses ecology, and of genesis of the whole environment.

This article represents mainly a preliminary analysis of the problem stated. This is an attempt to present the peculiarities of tendency of phytocenoses development under contrasting environmental conditions.

\section{ACKNOWLEDGEMENTS}

This scientific work have been made by financial support of the Integration Projects of Siberian Branch of Russian Academy of Sciences (NN 69, 77).

\section{REFERENCES}

[1] Berg, L.S. (1952) Soviet union geographic zones. Geografgiz, Moscow, 510.

[2] Sochava, V.B. (1968) Phytocenoses and native systems dynamics. Proceedings of Institute of Siberia and Far East Geography of USSR Academy of Sciences, 20, 1222.
[3] Lavrenko, Ye.M. (1970) Provincial dicision of Central Asia sub-region of Eurasia steppe region. Botanicheskii Zhurnal, 455, 609-625.

[4] Colwell, J.E. (1974) Vegetation canopy reflectance. Remote Sensing of Environment, 3, 175-183. doi:10.1016/0034-4257(74)90003-0

[5] Mynen, R.B., Keeling, C.D., et al., (1997) Increased plant growth in the northern high latitudes from 1981 to 1991. Nature, 386, 689-702.

[6] Anonym (1997) Ecotones in the biosphere. Nauka, Moscow, 326.

[7] Osipov, S.V. (2006) Notions "plakor" and "zonal habitat" and using of them while revealing zonal vegetation and zonal ecosystems. Izvestiya RAN, 2, 59-65.

[8] Zaleraev, V.S. (1997) Ecotones, ecotonal systems and problems of their classification. Problems of studies of marginal structures of biocenoses. Saratov, 4-5.

[9] Naiman, R., Decamps, H. and Fournier, F. (1989) Role of land/inland water ecotones in landscape management and restoration. Proposals for Collaborate Research. MABDigest 4, UNESCO, Paris, 94.

[10] Holland, M.M., Risser, P.G. and Naiman R.J. (1991) Ecotones. The role of landscape boundaries in the management and restoration of changing environmental. Chapman and Hall, New York, 142.

[11] Grishankov, G.Ye. (1977) Paragenetic system of native zones (in Crimea). Systematic Nature Investigations, Moscow, 128-139.

[12] Ivanovsky, L.N. (2001) Paragenese and paragenesis of mountains relief in southern Siberia. Institute of Geography of RAS SB Publishing House, Irkutsk, 142.

[13] Kulikov, A.I., Bazhenov, V.S. and Ivanov, N.V. (2006) Soils paragenesis and paradynamism. Buryat Scientific Center of RAS SB Publishing House, Ulan-Ude, 280. 